
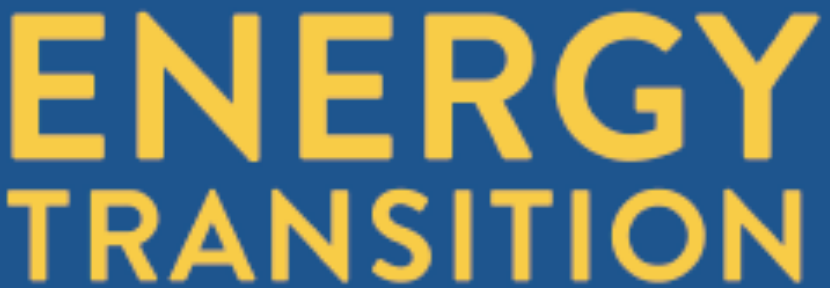

FINANCING CONSUMER CO-OWNERSHIP IN RENEWABLES

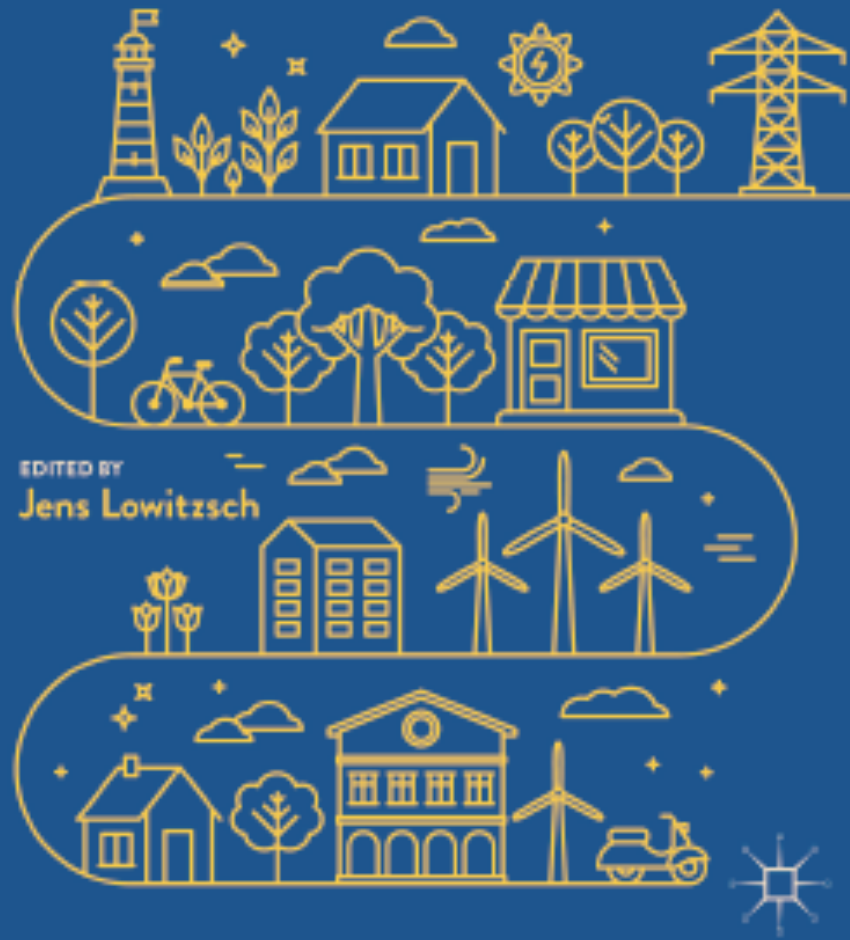




\title{
20
}

\section{Consumer (Co-)Ownership in Renewables in Switzerland}

\author{
Anna Ebers Broughel, Alexander Stauch, \\ Benjamin Schmid, and Pascal Vuichard
}

\begin{abstract}
A. Ebers Broughel $(\bowtie)$
Institute for Economy and the Environment (IWÖ-HSG), Good Energies Chair for Management of Renewable Energies, University of St. Gallen, St. Gallen, Switzerland e-mail: anna.ebers@unisg.ch
\end{abstract}

A. Stauch

Institute for Economy and the Environment (IWÖ-HSG), Good Energies Chair for Management of Renewable Energies, University of St. Gallen, St. Gallen, Switzerland

B. Schmid

Economics and Social Sciences, Swiss Federal Research Institute WSL, Birmensdorf, Switzerland

P. Vuichard

Institute for Economy and the Environment (IWÖ-HSG), Good Energies Chair for Management of Renewable Energies, University of St. Gallen, St. Gallen, Switzerland 


\subsection{Introduction}

\subsubsection{Energy Mix}

With a total final consumption of 854,300 TJ of energy in 2016 (Swiss Federal Office of Energy (SFOE) 2017a), Switzerland has one of the lowest $\mathrm{CO}_{2}$ per capita emissions among the developed nations (World Bank 2017). Still, Swiss final energy consumption is heavily reliant on fossil fuels: 34.2 per cent of energy comes from motor fuels (gasoline, diesel), 16.1 per cent from crude oil fuels, and 13.7 per cent from natural gas (SFOE 2017a). Renewable energy (RE) accounts for $22.1 \%$ of the overall energy mix, most of which is made up by hydropower (12.3 per cent), while solar photovoltaics (PV) and wind energy jointly contribute less than one per cent $(0.85 \%)$ (SFOE 2017b). RE contributes a similar share in the heating sector (20.2 per cent), with around half (52 per cent) of renewable heat originating from wood-fired boilers, followed by heat pumps (28 per cent) and waste (14 per cent) (ibid.).

In contrast, the Swiss electricity mix has traditionally been composed of non-fossil sources, mainly hydropower (59 per cent) and nuclear (32.8 per cent) in 2016 (SFOE 2017c). With around 500 large and 1000 small hydropower stations and 100 storage power plants, Switzerland is one of the countries with the highest shares of hydropower in the world (SFOE 2017b). Non-hydro renewable energy resources account for less than 6 per cent of the total electricity mix but are expected to grow in the future (SFOE 2017c).

\subsubsection{Main Challenges of the Energy Market, National Targets, and Specific Policy Goals}

Following the Fukushima nuclear meltdown in 2011, the Swiss government and parliament decided to phase out nuclear energy proposing an Energy Strategy 2050 (Energiestrategie 2050) (SFOE 2018). Nuclear is a major source for electricity generation in the country, marked by high uranium imports (Bundesamt für Energie 2016). After long deliberations, the Energy Strategy, now incorporated into the Energy Law (Energiegesetz, EnG), was put to public vote, and the first set of measures 
(erstes Massnahmenpaket) was approved by the majority of the Swiss population in a referendum in 2017 (ibid.). The updated Energy Law, in effect since 1 January 2018, stipulates several measures to increase energy efficiency and expand renewable energy generation. In addition, the existing five nuclear power plants are to remain operational as long as they are safe, but they will not be replaced by new ones, manifesting a gradual nuclear phase-out (ibid.). The first set of measures for the year 2020 includes the following: streamlining of the permitting procedures for building and interconnecting $\mathrm{RE}$ generation, increase of the $\mathrm{CO}_{2} \operatorname{tax}$ $\left(\mathrm{CO}_{2}\right.$-Abgabe $)$ to EUR 71.7 per ton, ${ }^{1}$ investment of EUR 384.3 million in the energy efficiency measures in the building sector. Starting from 2018, the grid surcharge on electricity consumers has been increased from EUR 0.013 to 0.02 per kilowatt hour, which will be collected to the fund (Netzzuschlagsfonds) that supports RE and energy efficiency projects (ibid.). The increase in the grid surcharge was necessary to somewhat close the gap between the limited availability of funds and large number of RE projects, which resulted in a substantial waiting list. For example, there were 568 hydropower, 379 wind, 369 biomass, and more than $34,000(34,447$ !) solar photovoltaic projects on the waiting list to receive the feed-in tariff (FIT) at the end of 2017 (Pronovo 2018).

The Energy Strategy also defines several ambitious targets for 2035. Relative to the year 2000, average energy and electricity consumption per capita should be reduced by 43 per cent and 13 per cent, respectively, while the production of electricity from wind, sun, biomass, and geothermal sources should increase to 11.4 terawatt hours, 3.5 times more than the total RE output in 2016 (SFOE 2017b; EnG, Art. 2 and 3).

\subsubsection{Ownership Structure in the Renewable Energy Sector}

The Swiss energy system is still dominated by large incumbent utilities, more than 80 per cent of which are owned by the public sector, such as cantons and municipalities (VSE 2018). Some of these energy

\footnotetext{
${ }^{1}$ As of 1 January 2018, the exchange rate of Swiss franc to EUR was 0.8541. http://www.finanzen. ch/waehrungsrechner/schweizer-franken-euro.
} 
companies are horizontally or vertically integrated. They are active at multiple stages of the value chain: electricity production, trading, distribution, or even across several divisions supplying electricity, gas, heat, or water (ibid.). Power-producing facilities, such as hydropower plants, are often (co-)owned by several utility companies (Partnerwerke), which receive the energy produced by the power plant in accordance with their ownership share (SFOE 2014). This ownership structure has a long history in Switzerland, making it difficult for small private investors to enter the market. At the same time, public ownership means that the country's citizens own the electricity-generating facilities.

- The up-to-date statistics about specific ownership structure of RE installations is hard to come by. Among the entities that receive the feed-in tariff, private investors and commercial entities (Gewerbe) hold less than $10 \%$ of installed capacity in small hydropower, while two-thirds of the capacity is owned by conventional energy companies and public entities (Chassot 2012). In contrast, almost half of the installed capacity in solar photovoltaic belongs to private individuals and about 30 per cent to commercial entities active outside the energy sector (ibid.). New cooperatives, founded after 1990, only own a very small share of PV capacity (Salm and Schmid 2016).

- Wind parks are built mostly in western Switzerland and are usually owned by big cantonal and city utilities. Smaller individual and community-owned projects exist, notably Goms and St Brais (ADEV 2018). Unlike in Germany, community ownership of wind installations (Bürgerwindenergiepark) is rare.

- As of 2016, there were about a hundred biogas facilities (found at large farms), while energy from waste was mainly sourced from paper, cardboard, waste, and sludge remaining from paper production (SFOE 2017b).

- No reliable statistics could be found for energy production by municipalities, schools, or small- and middle-sized enterprises and private persons. 


\subsection{The Consumer at the Heart of the Energy Market?}

\subsubsection{Consumer (Co-)Ownership in Renewable Energy Sources as Policy Goal}

For the purpose of this chapter, we define community finance broadly as a participation scheme that allows individuals, that is, small-scale retail investors, to invest in $\mathrm{RE}$ projects and receive compensation in form of electricity, certificates of origin (Herkunftsnachweis), and/or interest payments for a certain amount of time. Swiss Energy Law $(\mathrm{EnG})$ does not contain specific targets for expansion of consumer (co-) ownership of renewable energy sources (RES), but it does contain several provisions that encourage and support such (co-)ownership schemes (see also Sect. 20.3). One of them is an explicit authorization of selfconsumption (Eigenverbrauch), which states that producers can consume self-generated electricity entirely or partially at the place of generation (Federal Council 2016). Furthermore, the new version of the Federal Energy Law (2016) that was enacted in the beginning of 2018 allows the formation of self-consumption communities (Eigenverbrauchsgemeinschaften).

In the future, more institutional investors like pension funds might become active in financing RE infrastructure, due to the new legislation that creates a separate asset class for infrastructure investment (Weibel 2015). At the time of writing, one chamber of the parliament and the commission of the second chamber have approved this proposal, which makes the legislation likely to pass. However, due to significant investment volumes necessary for involvement of the institutional investors, large pension funds might not be the most appropriate actors for financing small-scale RE developments (Wüstenhagen et al. 2017). The scale issue might be addressed by the increased use of innovative platforms, which connect buyers and sellers of RE in a virtual marketplace (Reuter and Loocke 2017). Such platforms create new opportunities for crowdsourcing (gathering incremental contributions) to finance large RE projects 
but might potentially be used by the institutional investors to finance a portfolio of small-scale RE projects. ${ }^{2}$

\subsubsection{Fuel/Energy Poverty and Vulnerable Consumers}

The problem of energy poverty does not seem to loom large in Switzerland, which enjoys a universal electrification and ranks fourth in energy equity globally (World Energy Council 2018). This ranking suggests that energy is accessible and affordable to the Swiss population. The International Energy Agency defines 'modern energy access' as a consumption of over $500 \mathrm{kWh} /$ year per urban household (OECD/IEA 2010). The annual consumption of an average Swiss household is more than ten times greater: $5400 \mathrm{kWh}$ (Energieschweiz 2014). An average electricity bill for a Swiss household in 2015 was EUR 795, while the average gross annual household income was slightly below EUR 102,500 (Federal Statistical Office 2017; Statista 2018). Note that the electricity accounted for less than $0.8 \%$ of the average household's annual income, hardly a significant share. With proliferation of self-production and self-consumption of electricity, the average electricity consumer could face a slight increase of the electricity bill by EUR 10.7 per year, due to the distributive effect of recovering power grid costs (Kubli 2018).

\subsection{Regulatory Framework for Renewable Energy}

Due to the federalist structure, Swiss energy market is regulated on the federal, cantonal, and the municipal levels. Among the main federal statutory provisions are Energy Law (Energiegesetz, EnG) that incorporates the Energy Strategy 2050, Federal Energy Directive (Energieverordnung, EnV), Federal Electricity Supply Ordinance (Stromversorgungsverordnung,

\footnotetext{
${ }^{2}$ A recent survey has indicated that $20 \%$ of Swiss respondents would 'absolutely' participate in such local electricity trading and sharing marketplace, while another $60 \%$ would 'probably consider' that option (Reuter and Loocke 2017).
} 
StromVV), and Federal Act on the Reduction of $\mathrm{CO}_{2}$ Emissions (Bundesgesetz über die Reduktion der $\mathrm{CO}_{2}$-Emissionen, $\mathrm{CO}_{2}$ Gesetz) (Federal Council 2008, 2011, 2016, 2017). There are several federal agencies closely involved in energy questions: Swiss Federal Office of Energy (SFOE), Federal Department of the Environment, Transport, Energy and Communications (DETEC), and Environment, Spatial Planning and Energy Committees (ESPEC). More information on agencies and other players involved in the Swiss energy market is in Sect. 20.4.2.

The cantons often adopt their own cantonal energy directives and have cantonal agencies involved in steering cantonal energy policies. Large RE projects fall under the cantonal jurisdiction, while several federal authorities (including agencies in charge of civil aviation, military, meteorology, and spatial development) also have to issue appropriate permits (for detailed description of permitting process for large RE projects, see Wüstenhagen et al. 2017). Large RE projects need to be integrated into cantonal (or regional) structure (Richtplan) and land use (Nutzungsplan) plans and to receive a building permit, which might involve a referendum.

\subsubsection{Regulations for Connecting Renewable Energy Plants to the Grid}

Grid operators are obliged to purchase surplus electricity from small generators with installed capacity below $3 \mathrm{MW}$ or annual production below $5000 \mathrm{MWh}$ (SFOE 2017d). There are no special provisions for connecting the RE capacity installed by energy cooperatives to the grid. However, the remuneration for fed-in electricity is sometimes negotiated between the grid operator and the small generator. For additional income, small producers of RE can trade certificates of origin, which indicate the place and technology of production (SFOE 2016). Note that the Swiss electricity market is only partially liberalized and not integrated with the European market (UVEK 2018). Small end consumers of energy cannot switch between monopolistic electricity providers, and only larger consumers with annual consumption over $100,000 \mathrm{kWh}$ can choose their electricity supplier and can negotiate the electricity price. 
An important new regulatory provision is that a load course measurement requirement has been introduced for energy-generating systems over $30 \mathrm{kVA}$ that were installed before 31 December 2017 (UVEK 2017). Smart meters measure the fed-in electricity every 15 minutes and transmit these data to the measurement service provider, usually, the distribution grid operator (VESE 2018). This is another potential barrier for small RES producers, since measuring services cost between EUR 85.40 and EUR 1195.75 per year (ibid.). High costs might motivate small RES producers to opt for independent measurement services providers with more competitive rates. ${ }^{3}$

Long permitting and interconnection procedures are problematic for large and small installations alike. To address this bottleneck, the Energy Strategy obliged the cantonal authorities to establish more rapid permitting procedures for RE generators, while also granting them the status of 'national interest' (SFOE 2018). These measures are likely to reduce preconstruction risks of energy projects, especially in the wind sector. ${ }^{4}$ Moreover, wind energy permitting will be coordinated by a federal one-stop shop called 'guichet unique', considerably reducing project management complexity (Wüstenhagen et al. 2017).

\subsubsection{Support Policies (FITs, Auctions, Premiums, etc.)}

Year 2018 brings about a number of changes to the existing federal support policies for RE. Since 2009, electricity production from renewable sources has been supported through the payment of a feed-in tariff (Kostendeckende Einspeisevergütung, KEV). Updated legal provisions

\footnotetext{
${ }^{3}$ It is currently an object of political debate, whether the grid operators can reject the involvement of the independent providers and, thus, to monopolize the measurement services. The new Energy Directive stipulates that $80 \%$ of measuring devices in the grid should be replaced by smart meters by the end of 2027 (SFOE 2017d).

${ }^{4}$ Putting energy generation on equal footing with other national interests like nature and landscape protection will provide guidance to the 'weighting of interests' procedure performed by courts, which need to decide on the ecological and societal desirability of the proposed project. This change may be especially important for wind power projects that often take more than a decade in Switzerland to be approved and built (Wüstenhagen et al. 2017).
} 
stipulate that new projects may be considered for the feed-in-tariff payments until the end of 2022, while existing generators that already receive $\mathrm{KEV}$ will continue receiving the payments as planned (SFOE 2017 d). In 2018, the average KEV payment is cut by $10-20 \%$ (except for wind and hydropower), and the duration of the KEV payments is reduced from 20 years to 15 years (except for biomass) (ibid.). Starting from January 2020, larger electric generators with an installed capacity of over $100 \mathrm{~kW}$ will need to start directly marketing the generated electricity (Direktvermarktung), allowing the producers to receive the negotiated price and a feed-in premium (Einspeiseprämie).

A few additional technology-specific changes have also been announced. ${ }^{5}$ Instead of a feed-in tariff, solar photovoltaic installations between $2 \mathrm{~kW}$ and $50 \mathrm{MW}$ can apply for an investment subsidy (Einmalvergütung, EIV), which reimburses up to 30 per cent of the investment costs, determined by the investment costs of a reference solar plant (ibid.). The investment subsidies will be approved until 2030 and then phased out. Solar PV projects under $100 \mathrm{~kW}$ will not be eligible for the feed-in-tariff KEV and will only receive the investment subsidy EIV. Given the size of most residential systems, the investment subsidy EIV will be the dominant policy support instrument for solar prosumers in the coming decade. In addition, all Swiss cantons, except Lucerne, offer deductions of investment costs from taxable income (Swissolar 2015).

\subsubsection{Specific Regulations for Self-Consumption and Sale to the Grid}

Current energy statutes explicitly authorize consumption of self-generated electricity entirely or partially at the place of production (EnG, Art. 16). Moreover, prosumers do not have to pay additional charges (e.g. grid charges, KEV surcharges, ecological charges) for self-consumed electric

\footnotetext{
${ }^{5}$ Geothermal power will be supported with either a federal guarantee (Geothermie-Garantie) or an exploration subsidy (Erkungundsbeitrag), aimed at reducing the upfront risks of site exploration (SFOE 2017d). EIV will be used to support most of small-scale installations in biomass. Bioenergy installations will only be eligible for EIV (up to $20 \%$ of reference investment cost), while the bioenergy plants of regional importance may apply for either EIV or KEV.
} 
power (EKZ 2017). It has been estimated that self-consumption of electricity will become increasingly attractive to Swiss solar prosumers, resulting in up to $333 \mathrm{MW}$ of cumulative solar PV capacity by 2050 (Kubli 2018).

Another important legislative provision is the possibility to form selfconsumption communities (Eigenverbrauchsgemeinschaften) on adjacent plots of land, given that the community's electricity-generating capacity amounts to at least 10 per cent of the connected load (EnV, Art. 15). The law stipulates that the grid operator shall regard such a community as a single consumer. Thus, large self-consumption communities with electricity consumption of more than $100,000 \mathrm{kWh}$ a year could enter the liberalized market for large consumers. This provision opens new opportunities to community ownership projects, when neighbouring landowners or tenants at multi-family homes pool their demand for electricity and take advantage of self-consumption models or even electricity trading.

\subsection{Concepts for Consumer (Co-)Ownership in Practice}

\subsubsection{Contractual Arrangements and Corporate Vehicles Used}

The most basic form of consumer ownership is direct ownership of a generating facility. Despite it being the most widespread form of RE ownership, it has the disadvantage of making (co-)ownership dependent on the available infrastructure, for example, the availability of an appropriate rooftop for a solar PV installation, which excludes a large portion of the population like tenants from RE (co-)ownership. An alternative concept for (co-)ownership is 'solar leasing' paired with self-consumption and potentially energy storage. In this constellation, the interested citizen allows a solar installer to use their rooftop to produce electricity, which is subsequently self-consumed at the site based on a power purchase agreement. The installer takes care of the permitting and the technical side of the installation, including maintenance, making it easier for the rooftop owner to engage in the project (Ammann 2016). Interestingly, the leasing 
concepts give rise to new joint models, such as the case of an energy startup Younergy (http://www.younergy.ch), which partners with both the rooftop owners but also institutional investors whose funds are used to finance the solar installations (Ammann 2016).

Cooperatives are an established vehicle for consumer (co-)ownership both at the national and regional levels. ${ }^{6} \mathrm{~A}$ cooperative is an organization with 'the primary purpose of promoting or safeguarding the specific economic interests of the society's members by way of collective self-help' (Federal Council 1911, Code of Obligations, Art. 828). It is open to private individuals as well as to corporate and state actors (ibid., Art. 828, 926), with each member receiving exactly one vote based on the equity principle (ibid., Art. 855). Cooperatives have to be entered in the commercial register, but the cooperatives do not have an audit obligation (Purtschert 2005). Since 1990, more than a hundred new RE cooperatives have been founded, which are mainly active in the production of electricity from solar photovoltaics and heat from woodchips (Rivas et al. 2018). ${ }^{7}$ In 2016, around 30 per cent of the energy cooperatives active in electricity generation were applying self-consumption schemes (ibid.).

Swiss energy cooperatives often remain local with respect to their membership and location for installations (ibid.). Only around 10 per cent of the cooperatives own energy-generating capacity outside of their or neighbouring municipality, and only 3 per cent expand to another canton (ibid.). This might be a wise strategy, given that energy cooperatives consisting of citizens from the neighbourhood are considered as the most trustworthy actors to initiate and govern local electricity markets (Reuter and Loocke 2017). However, at least three cooperatives have a national or multi-regional reach: ADEV, Energiegenossenschaft Schweiz,

\footnotetext{
${ }^{6}$ Cooperatives have a long-standing tradition in Switzerland in a variety of economic sectors such as food retail, banking, insurances, dairy, and water supply (Purtschert 2005). Neither are cooperatives new to the energy sector. Already at the beginning of the twentieth century, several hundred of cooperatives emerged (mainly in rural areas) to build and manage the local distribution grids (Gugerli 1996). From estimated 1500 original energy cooperatives (Klemisch and Vogt 2012), roughly 150 are still active today with a few also engaging in the production of electricity from renewable sources (Schmid and Seidl 2018).

${ }^{7}$ Typically, these new cooperatives invest in a photovoltaics installation on a large rooftop of a school or a municipal building (ibid.). The produced electricity and the certificates of origin can be subsequently sold to the grid operator, to the cooperative members for self-consumption, or to other individual actors.
} 
Optima Solar (Rivas et al. 2018; Swissolar 2017). Similar to a cooperative, the establishment of a non-profit association is relatively simple, but unlike public ownership of a municipal plant, membership in an association requires active participation. ${ }^{8}$ There were at least 25 solar cooperatives and associations currently active on the regional level (Swissolar 2017).

In recent years, consumer (co-)ownership provided new opportunities for joint projects of different partners. For example, an installer, often a non-profit start-up, develops a RE project and partners with the utility to sell the project's shares to the utility's clients. The utility, in turn, delivers the produced 'green' electricity to their clients through their grid and manages the billing. In this setup, the consumer does not have to be a (co-)owner, which might prove attractive to a wider segment of population, especially tenants. New schemes can also involve a public entity (e.g. a cantonal or federal agency in charge of promotion of RES) and a non-energy company that promotes RES as part of their new business strategy (e.g. IKEA's solar business) or corporate social responsibility (e.g. COOP). There are emerging institutional investors and funds (like SUSI Partners) entering the RES business.

\subsubsection{Financing Conditions for Consumer (Co-) Ownership in Renewable Energy}

Swiss community finance projects obtain the same type of support from the agencies and associations as RES projects with a different ownership model. On the federal level, the most relevant agencies for RES are the Swiss Federal Office of Energy that oversees the energy transition in general, including the implementation of the SwissEnergy (EnergieSchweiz) programme (SFOE 2015); Pronovo AG (as subsidiary company of the

\footnotetext{
${ }^{8}$ Under Swiss law associations do not require certification or registration in the trade registry if the association does not conduct commercial operations nor is subject to an audit requirement. The audit is required when two of the following conditions are met in two consecutive years: total assets above EUR 8.5 million, turnover over EUR 17 million, and over 50 full-time jobs (Federal Council 1907, Swiss Civil Code (ZGB), Art. 61 and 65). This simplicity and flexibility make associations an attractive legal model for consumers interested in RES (co-)ownership; at the same time, the limited liability of their members, paired with low audit requirements, may restrict access to credit, making them reliant on equity capital.
} 
national transmission grid operator Swissgrid) that manages the feed-intariff (KEV) system, as well as the platform tracking the trade with the certificates of origin; the Swiss Federal Electricity Commission (ElCom) that acts as an independent regulatory authority in the Swiss electricity sector settling disputes regarding payments of the feed-in tariff; and the Federal Department of the Environment, Transport, Energy and Communications (UVEK) that oversees the grid surcharge fund.

In addition, there is a multitude of federal civil-society associations promoting and supporting RES. AEE Suisse (https://www.aeesuisse.ch) and the Swiss Energy Foundation (SES, https://www.energiestiftung.ch) are umbrella organizations representing interests of thousands of companies and energy producers all over Switzerland. The association of independent power producers (VESE, www.vese.ch) advises and represents RES producers that do not own their own distribution grid. Other associations have a technology-specific focus: Suisse Eole (http://www. suisse-eole.ch) represents wind power industry, while Swissolar (http:// www.swissolar.ch) works to promote solar interests, Holzenergie Schweiz represents wood, and Verband Fernwärme Schweiz (https://www.fernwaerme-schweiz.ch) represents district heating producers, while Ökostrom Schweiz (https://oekostromschweiz.ch) works with agricultural biogas plant operators. Many other associations operate on the regional, cantonal, or local level, and they are too numerous to list. For example, the regional Albert-Köchlin-Foundation (http://aks-stiftung.ch/stiftung) promotes the establishment of new energy cooperatives in central Switzerland. Solarplattform Seeland (http://www.solarplattformseeland. ch) supports regional, sustainable energy production with solar PV in the Northwest of Switzerland. A number of cantons have a specialized energy agency like Energieagentur (http://www.energieagentur-sg.ch) in the canton of St Gallen, which assists citizens and project developers alike with their energy questions.

Public-private partnerships (PPP) can help promote RES projects, even involving the players outside of energy industry. For example, EnergieSchweiz collaborated with COOP (a large Swiss retailer, itself a cooperative) and Swiss dairy farmers (Märki and Angele 2012). While EnergieSchweiz provided important informational and technical guidance to the involved farmers, the financial support for the project came from 
the sustainability fund of COOP. The supported bioenergy projects received a grant of up to EUR 171,000 for reimbursement of investment costs and an optional zero-interest rate loan. This financial support allowed the projects to successfully obtain further necessary financing from the banks, which is often not an easy task given the large upfront investment (ranging between EUR 1 and 2 million).

\subsubsection{Examples of Consumer (Co-)Ownership}

Consumer (co-)ownership is still an emerging form of ownership model of renewable energy generation in Switzerland, yet some interesting examples can be found.

I. Elektrizitätswerke Zürich (EWZ), a utility of the city of Zürich, has offered its customers the possibility to purchase shares of locally installed solar plants since 2014 (EWZ 2017). After buying a certain number of 'square metres' of a chosen solar plant, the EWZ customers annually receive $80 \mathrm{kWh}$ of solar electricity per purchased square metre, for the duration of 20 years. If the consumer wants to cancel their contract due to a move or some other circumstances, these shares can be sold back to EWZ. The model's success is evident from the fact that the EWZ sold out within a matter of days six large solar plants (between 1000 and $2500 \mathrm{~m}^{2}$ ) (EWZ 2017). As of 2018, there were several more examples of municipal solar schemes in Switzerland, for example, Miinstrom (http:// www.miinstrom.ch) and Waldsolar (http://waldsolar.ch/solar-beteiligung/).

II. Another example of a partnership that promotes citizen (co-)ownership of renewable energies is the collaboration between Sunraising Bern (https://sunraising.ch), a non-profit start-up founded in 2015, and electric utility Energiewerke Bern (EWB) (SunRaising 2017). As its name suggests, Sunraising stands for a combination of sun power and fundraising, offering the residents of Bern the possibility to buy a share representing a certain number of square metres of a locally installed solar plant. As compensation, the customers of Sunraising receive a respective share of electricity from solar power for free for 20 years, which roughly corresponds to the life cycle of a solar plant. In this setup, Sunraising is in 
charge of installing the solar panels and their maintenance, as well as selling the shares of the solar plant. The produced solar power is fed into the electric grid managed by the EWB, which delivers the electricity to the Sunraising customers. Since 2016 more than 250 consumers invested CHF 385,000 (EUR 338,000) in eight rooftop PV installations with a capacity of about $100 \mathrm{kWp}$.

III. Energiegenossenschaft Schweiz (EGch) was founded in 2012 with the aim of setting up the largest decentralized solar power plant in Switzerland by creating 'electricity commons' (Stromallmende) that consist of small energy producers and consumers (Energiegenossenschaft Schweiz 2018). In the starting year 2012 around CHF 350,000 (EUR $310,000)$ were invested. The annual general assembly of EGch acts as an exchange platform for certificates of origin, where electricity consumers and producers negotiate a price for purchase and sales. In 2017, the certificates cost EUR 0.06/kWh for the consumer, of which EUR 0.043/ $\mathrm{kWh}$ were received by the producer and EUR $0.071 / \mathrm{kWh}$ by EGch to cover its administrative costs (ibid.).

IV. Energiegenossenschaft Buttisholz (www.energie-buttisholz. ch) founded in 2013 has a local reach operating under the slogan 'locally produced-locally consumed'. The aim is to provide opportunities for the inhabitants of Buttisholz to collectively shape their energy future. In cooperation with the municipality, the cooperative finances and runs solar PV installations on the rooftop of the local school (Energie Genossenschaft Buttisholz 2018). The cooperative is firmly embedded in the local community by organizing informational events at schools and at industrial exhibitions, as well as forming partnerships with local businesses (ibid., personal correspondence). Most Swiss energy cooperatives resemble the local Energiegenossenschaft Buttisholz (Rivas et al. 2018).

V. Founded in 1991 in the canton of Appenzell with the slogan 'action instead of words', the association Appenzeller Energie (www.appenzeller-energie.ch) was a reaction by a bi-partisan group of politicians to the nuclear accidents in the Three Mile Island and Chernobyl. In 2017, the association had about 200 members, with the aim to promote the purchase, distribution, and use of RE. Appenzeller Energie has been involved in the construction of RE-generating facilities, including two 
solar photovoltaic installations, three small hydroelectric power stations, one wind turbine, and one solar thermal system, cumulatively generating between 400 and 500 MWh of electricity annually (Appenzeller Energie 2017). The generated electricity is sold to the grid operator as 'grey' electricity, while the consumers in the region can purchase the certificates of origin for EUR $0.136 / \mathrm{kWh}$ (ibid.). Membership in the association is not required for the purchase of the certificates, neither is the certificate purchase necessary for the membership (ibid.). Appenzeller Energie has a strong regional focus offering workshops for self-building of solar thermal system and cooperating with students in energy-related school projects (ibid.).

\subsection{Factors Affecting the Financing of Renewable Energy Sources and Barriers to Consumer (Co-) Ownership}

\subsubsection{Political, Legal, and Administrative Factors}

Consumer (co-)ownership of RES might be harmed by the absence of electricity market liberalization in the small-consumer segment. Since utilities have a stable customer base, an interactive relationship between customers and municipalities is rare (Schicht et al. 2012). Moreover, the incumbent utilities have significant market power when negotiating with new market entrants, be it an interconnection issue or a power purchase agreement (Girod et al. 2014). New market entrants, who offer consumer (co-)ownership of RES, must collaborate with the local utilities to dispatch the produced electricity to private consumers via the local power grid. It is likely that with market liberalization and increased consumer (co-)ownership of RES, the utilities will change from product-oriented towards more service-oriented organizations, paying more attention to customer satisfaction and retention rates (Schicht et al. 2012). 
Despite having been introduced to help RES projects, the feed-intariff system created obstacles to the development of community RES projects. ${ }^{9}$ The KEV feed-in-tariff system suffers from underfinancing, which leads to a very long waiting list of energy projects waiting to be considered for the payments. It is estimated that only a third of currently producing solar projects receive the feed-in tariff (VESE 2016). Even though most wind projects receive the feed-in tariff, the exact remuneration rates are not determined until the project is operational, which again creates considerable uncertainties for project developers with respect to their cash flows and hinders project finance (Wüstenhagen et al. 2017). Wind projects also face considerable risks in the pre-construction stage, which make wind project development prohibitively long and expensive for smaller players (ibid.). Finally, the new Energy Law (EnG) stipulates altered support schemes for RE projects (notably, phase-out of KEV). Some of these projects, which are suitable for citizen participation, will never materialize without the feed-in tariffs.

\subsubsection{Economic and Management Factors}

In case of small non-profit organizations, a major barrier is their limited administrative capacity. For example, only about 25 per cent of cooperatives have paid positions, while the majority of cooperatives rely solely on voluntary work (Rivas et al. 2018). ${ }^{10}$ This makes it difficult for many cooperatives to handle complex and costly regulatory procedures or to set up effective marketing campaigns. Being civic organization with participatory decision-making and flat hierarchical structures, cooperatives might struggle to find their identity as a professional organization with growth aspirations.

\footnotetext{
${ }^{9}$ It should be noted that Swiss feed-in-tariff levels are rather generous in international comparison (RES Legal EU 2018). This might be a necessity given the differences in price levels and smaller size of the Swiss electricity market compared to other countries.

${ }^{10}$ Despite the high approval of energy cooperatives, the recent survey has shown that the Swiss respondents are generally not willing to volunteer their time for cooperatives (Reuter and Loocke 2017).
} 
Furthermore, there is a remarkable heterogeneity among the potential investors. ${ }^{11}$ The community finance sector might benefit from addressing the issues that are most important for their target investor group. One of the major reasons for the Swiss population to forego investment into community RE projects is limited information about community finance (Ebers and Hampl 2016; Gamma et al. 2017). To realize the considerable market potential for community finance in Switzerland, these barriers need to be addressed through consumer education and spread of information about risk-return profile of community energy projects, while adapting the projects to the heterogeneous tastes of different investor segments (Ebers and Hampl forthcoming).

\subsubsection{Cultural Factors}

Over the recent years, the surveys observe a high and consistently growing preference for renewable and locally produced energy sources among the Swiss citizens (Ebers and Wüstenhagen 2016; Gamma et al. 2017; Reuter and Loocke 2017). Indeed, contribution to environmental protection and energy transition (65\%) was cited as the main motivation to invest into community finance, followed by increased independence from electricity imports (54\%) and a contribution to the local community (26\%) (Gamma et al. 2017). RES community projects might also become increasingly attractive due to their positive, although conservative, return potential. ${ }^{12}$ Even though financial motivations lag behind other considerations, about a fifth $(21 \%)$ of the Swiss consumers regard financial returns as one of the two main reasons for investing in renewable energy projects (ibid.).

\footnotetext{
${ }^{11}$ The largest group of potential investors into community RES projects can be described as 'urban wind energy enthusiasts' (55.8\% of all investors), who are predominantly renters $(56.4 \%)$ with college education (46.4\%) (Ebers and Hampl 2017). Yet, there was a significant segment of investors, who lived in the rural areas $(28.9 \%)$ or were not welcoming to wind power near their residence $(22.0 \%)$ (ibid.).

${ }^{12}$ For example, solar cooperative ADEV has offered the annual returns of $2 \%-2.5 \%$ to its members in the last decade, while the savings accounts in the major Swiss banks have lower or even negative interest rates (ADEV 2017; Ebers and Hampl 2016).
} 
Generally, consumer surveys identify a considerable market potential for community projects in Switzerland: about 60\% of respondents said that they would be interested (or may be interested) in investing into a community-owned RES (Ebers and Wüstenhagen 2015; Gamma et al. 2017). On average, potential investors tended to have higher level of education, be more optimistic about renewable energy achieving the grid parity, believe into the future without fossil fuels, and be more welcoming to wind energy projects in their communities (Ebers and Hampl forthcoming). About 1.9\% of the German- and French-speaking population in Switzerland have already invested into community finance (compare to $7 \%$ in Austria) (Ebers and Hampl forthcoming; Gamma et al. 2017).

\subsection{Possible Future Developments and Trends for Consumer (Co-) Ownership}

Energy issues have been the centre of the public discourse in the last few years in Switzerland, resulting in several energy referenda and the adoption of the Energy Strategy 2050. However, Swiss energy policy is likely to remain in flux in the coming years. One of the major changes will be the replacement of the current feed-in-tariff system with a steering policy, which could include an energy steering charge (Lenkungsabgabe). The Department of Finance is also considering an ecological tax reform. It is yet to be seen whether these policy proposals would have a positive or negative impact on community finance. Similarly, it is unclear whether liberalization of the electricity market, as currently discussed in the Swiss parliament, would address the current challenges faced by the community RE projects.

Market liberalization might have both positive and negative effects on consumer (co-)ownership of RE. A liberalized market is likely to boost the number of consumer (co-)ownership offers by utilities, who would be seeking to respond to customer preferences for local projects. Another advantage of a liberalized market is a higher bargaining power of the small-scale generators with respect to the electricity prices and certificates 
of origin, as they might be able to market those directly to the end consumer. On the other hand, market liberalization is likely to create even more economic pressure on the incumbent utilities. In turn, small energy producers (especially energy cooperatives) will be put under pressure to innovate their business models and to professionalize their operations. It should be remembered that consumer (co-)ownership models thrive with local embeddedness and a democratic and equitable decision-making (Tabi and Wüstenhagen 2017), which might run contrary to the efforts of professionalization and streamlining.

Perhaps unlikely, a liberalized market might lead to a price battle between incumbent utilities and new market entrants, who will become direct competitors rather than partners. Even if the prices for electricity drop considerably, it might not motivate the consumers enough to switch the providers, as nearly a half ( 44 per cent) of Swiss electricity customers were not aware of the size of their electricity bill (Gamma et al. 2017). In sum, a fully liberalized electricity market will create a number of opportunities and threats for community finance projects, while specific regulatory provisions will determine the final outcome.

There are several approaches to further scale up and diffuse consumer investments in RES in Switzerland, which rely on intensified cooperation between all involved stakeholders. Intensified collaboration could take place among small-scale RES project developers themselves, safeguarding their common interests in the political arena. The second type of collaboration could be between community finance project developers and the grid operators to agree on the fair pricing for the fed-in electricity. Currently, the remuneration for solar electricity varies massively among geographic regions and grid operators (there are 650 of them in Switzerland), ranging from less than EUR $0.034 / \mathrm{kWh}$ to more than EUR 0.17/kWh (VESE 2017). To reach such an agreement, small-scale producers may want to secure the support from local municipalities that often own the grid operators. Municipalities might also have the necessary resources with respect to marketing, know-how, and access to potential clients, which could be helpful for promotion of RES projects organized by the smaller non-profit entities. 


\section{References}

ADEV. (2017). Genossenschaftsanteile. Retrieved January 5, 2018, from https:// www.adev.ch/de/adev/oekologische-geldanlage/genossenschaftsanteile.html. ADEV. (2018). Windkraft. Retrieved January 6, 2018, from https://www.adev. $\mathrm{ch} / \mathrm{de} / \mathrm{adev} / \mathrm{dezentrale-stromproduktion/windkraft/.}$

Ammann, K. (2016, September 17). Tiefe Kosten für Solaranlagen-Leasing sei Dank. SRF. Retrieved January 4, 2018, from https://www.srf.ch/news/ wirtschaft/tiefe-kosten-fuer-solaranlagen-leasing-sei-dank.

Appenzeller Energie. (2017). Appenzeller Energie_Vereinigung zur Förderung umweltfreundlicher Energien. Retrieved February 28, 2018, from http://www. appenzeller-energie.ch/.

Bundesamt für Energie. (2016). Kernenergie. Retrieved from http://www.bfe. admin.ch/themen/00511/.

Chassot, S. (2012). Wer investiert in der Schweiz in erneuerbare Energien? Eine Auswertung der Anmeldungen zur Kostendeckenden Einspeisevergütung (KEV), Stand April 2012. University of St.Gallen, St.Gallen. Retrieved December 11, 2017, from https://iwoe.unisg.ch/iwoe-news/2012/20121213_kev-bericht.

Ebers, A., \& Hampl, N. (2016). Community financing of renewable energy projects in the age of low and negative interest rates in Austria and Switzerland. In F. Taisch, A. Jungmeister, \& H. Gernet (Eds.), Cooperative identity and growth. Verlag Raiffeisen Schweiz. Retrieved March 20, 2018, from https:// www.alexandria.unisg.ch/249528/.

Ebers, A., \& Wüstenhagen, R. (2015). 5th consumer barometer of renewable energy. University of St.Gallen. Retrieved October 16, 2017, from https:// www.alexandria.unisg.ch/249530.

Ebers, A., \& Wüstenhagen, R. (2016). 6th consumer barometer of renewable energy. University of St.Gallen. Retrieved October 16, 2017, from https:// www.alexandria.unisg.ch/249529/.

Ebers Broughel, A., \& Hampl, N. (accepted, in production). Community financing of renewable energy projects in Austria and Switzerland: Profiles of potential investors. Energy Policy.

EKZ. (2017). Photovoltaik-Anlagen. Nutzen Sie Ihr Dach. Retrieved January 4, 2018, from http://www.ekz.ch/de/unternehmen/strom-produzieren-unternehmen/pv-anlagen.html.

Energie Genossenschaft Buttisholz. (2018). Projekte. Retrieved March 3, 2018, from http://www.energie-buttisholz.ch/. 
Energiegenossenschaft Schweiz. (2018). Stromallmend. Retrieved February 28, 2018, from http://www.energiegenossenschaft.ch/wp2/stromallmend-2/.

Energieschweiz. (2014). Energieeffizienz im Haushalt. Bundesamt für Energie.

Retrieved March 17, 2018, from http://www.energieeffizienz.ch/dam/ studien/2013_typischer_haushalt_stromverbrauch_d/pdf_de/SAFE_ typischer_Haushaltstromverbrauch_12_2013/Der\%20typische\%20 Haushalt-SV-SAFE-Dez-2013.pdf.

EWZ. (2017). Energie produzieren für Private—an Solaranlage beteiligen: Ewz. solarzüri. Retrieved October 14, 2017, from https:/www.ewz.ch/de/private/ energie-produzieren/an-solaranlage-beteiligen.html.

Federal Council. (1907). Swiss civil code (ZGB), status as of 1 September 2017. Retrieved March 20, 2018, from https://www.admin.ch/opc/en/classifiedcompilation/19070042/201801010000/210.pdf.

Federal Council. (1911). Federal act on the amendment of the swiss civil code. Part five: The code of obligations of 30 March 1911. Status as of April 1, 2017. Retrieved March 20, 2018, from https://www.admin.ch/opc/en/classifiedcompilation/19110009/index.html.

Federal Council. (2008). Federal electricity supply ordinance (Stromversorgungsverordnung, StromVV). Änderung vom 1. November 2017. Retrieved March 20, 2018, from https:/www.admin.ch/opc/de/officialcompilation/2017/7109.pdf.

Federal Council. (2011). Federal act on the reduction of $\mathrm{CO}_{2}$ emissions, $\left(\mathrm{CO}_{2} \mathrm{Act}\right)$ of 23 December 2011. Status as of 1 January 2013. Retrieved March 20, 2018, from https://www.admin.ch/opc/en/classified-compilation/20091310/ index.html.

Federal Council. (2016, September). Swiss federal energy law (EnG). Energiegesetz vom 30. Stand am 1. January 2018. Retrieved January 4, 2017, from https:// www.admin.ch/opc/de/classified-compilation/20121295/index.html.

Federal Council. (2017, November). Swiss federal energy directive (EnV), 2017. Energieverordnung vom 1. Stand am 1. January 2018. Retrieved January 4, 2018, from https://www.admin.ch/opc/de/classified-compilation/20162945/ index.html.

Federal Statistical Office. (2017). Haushaltseinkommen und Ausgaben sämtlicher Haushalte nach Jahr. Retrieved December 5, 2017, from https:/www.bfs. admin.ch/bfs/de/home/statistiken/wirtschaftliche-soziale-situation-bevoelkerung/einkommen-verbrauch-vermoegen/haushaltsbudget.assetdetail.3865767.html. 
Gamma, K., Stauch, A., \& Wüstenhagen, R. (2017). 7th consumer barometer of renewable energy. University of St.Gallen. Retrieved October 16, 2017, from www.iwoe.unisg.ch/kundenbarometer.

Girod, B., Lang, T., \& Naegele, F. (2014). Energieeffizienz in Gebäuden: Herausforderungen und Chancen für Energieversorger und Technologiehersteller. Retrieved October 20, 2017, from http://www.sustec.ethz.ch/content/dam/ ethz/special-interest/mtec/sustainability-and-technology/PDFs/SER_Final_ report.pdf.

Gugerli, D. (1996). Redeströme. Zur Elektrifizierung der Schweiz; 1880-1914. Zürich: Chronos.

Klemisch, H., \& Vogt, W. (2012). Genossenschaften und ihre Potenziale für eine sozial gerechte und nachhaltige Wirtschaftsweise. WISOZ Diskurs, Bonn, Friedrich-Ebert-Stiftung. Retrieved February 28, 2018, from https://www. fes.de/abteilung-wirtschafts-und-sozialpolitik/publikationen-sortiert/wisodiskurs/?tx_digbib_digbibpublicationlist $\% 5$ BpageIndex $\% 5 \mathrm{D}=13 \& \mathrm{cHash}=$ bc7c110ba13559badbba0395e8ac8a70.

Kubli, M. (2018). Squaring the sunny circle? On balancing distributive justice of power grid costs and incentives for solar prosumers. Energy Policy, 114, 173-188.

Märki, A., \& Angele, H.-C. (2012). Naturafarm_Biogas50. Final report. p. 19. Swiss Federal Office of Energy. Retrieved January 4, 2018, from https://www. newsd.admin.ch/newsd/message/attachments/26745.pdf.

OECD/IEA. (2010). Energy poverty. How to make modern energy access universal. Retrieved March 17, 2018, from http://www.worldenergyoutlook.org/ media/weowebsite/2010/weo2010_poverty.pdf.

Pronovo. (2018). Berichte und Publikationnen. Kockpit KEV 2017-Q4. 12.01.2018. Retrieved March 17, 2018, from https://pronovo.ch/landingpage/services/berichte/\#.

Purtschert, R. (Ed.). (2005). Das Genossenschaftswesen in der Schweiz. Bern: Haupt.

RES Legal EU. (2018). Legal sources on renewable energy. Retrieved March 20, 2018, from http://www.res-legal.eu/search-by-country/switzerland/summary/ c/switzerland/s/res-e/sum/395/lpid/396/.

Reuter, E., \& Loocke, M. (2017). Empowering local electricity markets. A survey study from Switzerland, Norway, Spain, and Germany. Retrieved from https://www.alexandria.unisg.ch/252125/1/Broschuere_Empower_WEB. pdf. 
Rivas, J., Schmid, B., \& Seidl, I. (2018). Energiegenossenschaften in der Schweiz. WSL Bericht. Retrieved from https://www.wsl.ch/de/publikationensuchen/ wsl-berichte.html.

Salm, S., \& Schmid, B. (2016). Finanzierung von erneuerbaren Energien über Bürgerbeteiligungsmodelle. AEE Suisse, Finanzwirtschaft und EnergiezukunftChancen intelligent nutzen, 16-19.

Schicht, R., Mueller, M., Niemeyer, C., Frank, M., Muster, S., \& Meier, M. (2012). Schweizer Stromwirtschaft zwischen Abwarten und AktivismusStandortbestimmung der Schweizer Energieversorgungsunternehmen. Retrieved October 21, 2017, from https://www.strom.ch/uploads/media/ BCG-VSE_Studie-Stromwirtschaft_06-2012_01.pdf.

Schmid, B., \& Seidl, I. (2018). Zivilgesellschaftliches Engagement und Rahmenbedingungen für erneuerbare Energie in der Schweiz. In L. Holstenkamp \& J. Radtke (Eds.), Handbuch Energiewende und Partizipation (pp. 1093-1106). Wiesbaden: Springer.

Statista. (2018). Annual household electricity bill in Switzerland. Retrieved October 15,2017, from http://de.statista.com/statistik/daten/studie/330478/ umfrage/jaehrliche-stromrechnung-privater-haushalte-in-der-schweiz/.

SunRaising. (2017). Die Solardach Challenge: Dein Solarstrom, Anleitung, FAQs, Über Uns. Retrieved October 11, 2017, from https://sunraising.ch/challenge/anleitung/.

Swiss Federal Office of Energy. (2014). Kostenstruktur und Kosteneffizienz der Schweizer Wasserkraft. Retrieved November 10, 2017, from http://www.bfe. admin.ch/php/modules/publikationen/stream.php?extlang=de\&name =de_876305500.pdf.

Swiss Federal Office of Energy. (2015). SwissEnergy-The programme for energy efficiency and renewable energy. Retrieved February 28, 2018, from http://www.bfe.admin.ch/energie/00458/index.html?lang=en\&dossier_ id $=06657$.

Swiss Federal Office of Energy. (2016). Herkunftsnachweis für Elektrizität und Stromkennzeichnung. Retrieved January 4, 2018, from http://www.bfe. admin.ch/themen/00612/00614/index.htmlllang=de.

Swiss Federal Office of Energy. (2017a). Schweizerische Gesamtenergiestatistik 2016. Retrieved October 14, 2017, from http://www.bfe.admin.ch/themen/00526/00541/00542/00631/index.html?lang=de\&dossier_ id $=00763$.

Swiss Federal Office of Energy. (2017b). Schweizerische Statistik der erneuerbaren Energien. Retrieved October 24, 2017, from http://www.bfe.admin.ch/themen/00526/00541/00543/index.html?lang=de\&dossier_id=00772. 
Swiss Federal Office of Energy. (2017c). Schweizerische Elektrizitätsstatistik 2016. Retrieved October 25, 2017, from http://www.bfe.admin.ch/themen/00526/00541/00542/00630/index.html?lang=de\&dossier_ $\mathrm{id}=00765$.

Swiss Federal Office of Energy. (2017d). Wichtigste Neuerungen im Energierecht 2018. Retrieved January 4, 2018, from https://www.newsd.admin.ch/newsd/ message/attachments/50166.pdf.

Swiss Federal Office of Energy. (2018). Energiestrategie 2050. Retrieved January 2, 2018, from http:/www.bfe.admin.ch/energiestrategie2050/ index.html?lang=de.

Swissolar. (2015). Kantonale und eidgenössische Steuerpraxis. Retrieved January 5, 2018, from http://www.swissolar.ch/fileadmin/user_upload/Shop/21009_ Merkblatt_Steuerpraxis.pdf.

Swissolar. (2017). Verzeichnis der Solargenossenschaften. Retrieved January 5, 2018, from http://www.swissolar.ch/fileadmin/user_upload/Bauherren/ 170814_Solargenossenschaften.pdf.

Tabi, A., \& Wüstenhagen, R. (2017). Keep it local and fish-friendly: Social acceptance of hydropower projects in Switzerland. Renewable and Sustainable Energy Reviews, 68, 763-773.

UVEK. (2017). Ausführungsbestimmungen zum neuen Energiegesetz vom 30. September 2016, Teilrevision der Stromversorgungsverordnung, Erläuterungen. Retrieved March 3, 2018, from http://www.bfe.admin.ch/energiestrategie2050/index.html?lang=de\&dossier_id=06919.

UVEK. (2018). Öffnung des Strommarktes. Retrieved March 20, 2018, from https://www.uvek.admin.ch/uvek/de/home/energie/oeffnung-strommarkt. html.

VESE. (2016). Kostendeckende Einspeisevergütung für Solarstrom. VESE press release. Retrieved January 5, 2018, from https://www.energie-cluster.ch/ admin/data/files/file/file/1650/vese_medienmitteilung_kevtarife2017. pdf? $1 \mathrm{~m}=1486626798$.

VESE. (2017). Alle Tarife der Elektrizitätswerke im Vergleich. Retrieved January 5, 2018, from http://www.vese.ch/pvtarif-apps/.

VESE. (2018). Lastgangmessung. Retrieved March 3, 2018, from http://www. vese.ch/lastgangmessung/.

VSE. (2018). Stromversorgung. Retrieved November 12, 2017, from https:// www.strom.ch/de/energie/energiefakten/stromversorgung.html.

Weibel, T. (2015). Infrastrukturanlagen für Pensionskassen attraktiver machen. Retrieved January 5, 2018, from https://www.parlament.ch/de/ratsbetrieb/ suche-curia-vista/geschaeft?AffairId=20153905. 
World Bank. (2017). CO2 emissions (metric tons per capita). Carbon Dioxide Information Analysis Center, Environmental Sciences Division, Oak Ridge National Laboratory, TN. Retrieved January 4, 2018, from https:// data.worldbank.org/indicator/EN.ATM.CO2E.PC?year_high_ desc $=$ false.

World Energy Council. (2018). Energy profile Switzerland. Retrieved March 17, 2018, from https://trilemma.worldenergy.org/\#!/country-profile?country= Switzerland \&year $=2017$.

Wüstenhagen, R., Blondiau, Y., Ebers, A., \& Salm, S. (2017). Lowering the financing cost of Swiss renewable energy infrastructure: Reducing the policy risk premium and attracting new investor types. Report SI/501293-01. Swiss Federal Office of Energy. Retrieved January 4, 2018, from https://www.aramis.admin.ch/Default.aspx?DocumentID=45844\&Load=true. 